Theoretical-empirical Article

\title{
Antecedents of Commitment to Budgetary Goals
}

\section{Antecedentes do Compromisso com as Metas Orçamentárias}

\author{
Daniele Cristina Bernd*1 $\odot$ \\ Ilse Maria Beuren ${ }^{10}$ \\ Celliane Ferraz Pazetto' $\odot$ \\ Carlos Eduardo Facin Lavarda ${ }^{10}$
}

\section{ABSTRACT}

Objective: this study analyzes the interactions between budgetary participation, motivation at work (intrinsic and extrinsic), and commitment to budgetary goals. Methods: a survey was carried out with 131 intermediate level managers from different organizational areas of companies classified among the best and biggest companies in Brazil. Results: the results of modeling structural equations indicate that intrinsic and extrinsic motivations have different roles in their interactions with budgetary participation and commitment to goals. And their involvement in the budgetary process reveals behavioral and motivational effects. Conclusions: it is concluded that participation in the budgetary process can positively reflect on managerial performance, insofar as it is able to trigger intrinsic motivational effect and favor behaviors aimed at the commitment to budgetary goals.

Keywords: budgetary participation; motivation at work; commitment to budgetary goals.

\section{RESUMO}

Objetivo: este estudo analisa as interaçóes entre a participação orçamentária, a motivação no trabalho (intrínseca e extrínseca) e o compromisso com as metas orçamentárias. Métodos: uma survey foi realizada com 131 gestores de nível intermediário de diferentes áreas organizacionais de empresas classificadas entre as melhores e maiores empresas do Brasil. Resultados: os resultados da modelagem de equaçôes estruturais indicam que as motivaçóes intrínsecas e extrínsecas apresentam papéis distintos em suas interaçóes com a participação orçamentária e o compromisso com as metas. E o envolvimento destes com o processo orçamentário revela efeitos comportamentais e motivacionais. Conclusóes: conclui-se que a participação no processo orçamentário pode refletir positivamente no desempenho gerencial, na medida em que é capaz de desencadear efeito motivacional intrínseco e favorecer comportamentos voltados ao compromisso com as metas orçamentárias.

Palavras-chave: participação orçamentária; motivação no trabalho; compromisso com as metas orçamentárias.

1. Universidade Federal de Santa Catarina, Programa de Pós-graduação em Contabilidade, Florianópolis, SC, Brazil.

Cite as: Bernd, D. C., Beuren, I. M., Pazetto, C. F., \& Lavarda, C. E. F. (2022). Antecedents of commitment to budgetary goals. Revista de Administração Contemporânea, 26(2), e200018. https://doi.org/10.1590/1982-7849rac2022200018.en
}

\# of invited reviewers until the decision:

\begin{tabular}{|c|c|c|c|c|c|c|c|c|c|c|c|c|c|c|c|c|c|c|}
\hline & 1 & 2 & 3 & 4 & 5 & 6 & 7 & 8 & 9 & 10 & 11 & 12 & 13 & 14 & 15 & 16 & 17 & 18 \\
\hline $1^{\text {st }}$ round & $x$ & $x$ & $x$ & $x$ & (x) & $x$ & $x$ & $x$ & $x$ & $x$ & $x$ & $x$ & $x$ & $\stackrel{\phi}{2}$ & $x$ & $x$ & $x$ & 9 \\
\hline $2^{\text {nd }}$ round & $x$ & (x) & & & & & & & & & & & & & & & & \\
\hline
\end{tabular}

Editor-in-chief: Wesley Mendes-da-Silva (Fundação Getulio Vargas, EAESP, Brazil) Reviewers: Renata Braga Berenguer de Vasconcelos (Universidade Federal de Pernambuco, Brazill) Cristina Viana de Jesus (Universidade Federal de Santa Catarina, PPGC, Brazill) Peer Review Report: The Peer Review Report is available at this external URL. 


\section{INTRODUCTION}

The budget is an instrument commonly used for management control (Frezatti, 2009), due to its significant contribution to assess managerial performance and influence the attitudes and behaviors of individuals in the workplace (Covaleski, Evans III, Luft, \& Shields, 2007), providing different reactions and human interactions (Milani, 1975), which may imply greater efforts to achieve budgetary goals (Jacomossi, Schlup, \& Zonatto, 2018; Lunardi, Zonatto, \& Nascimento, 2020; Milani, 1975; Shields \& Shields, 1998). Thus, the way to increase the effectiveness of the budget is to provide an increase in the budget participation of managers (Hassel \& Cunningham, 1993).

Participation in the budget process, given its ability to influence the cognition and motivation of subordinates (Chong, Eggleton, \& Leong, 2005) and exercise an informational function in organizations (Maiga, 2005), can lead to a demeanor improvement in the labor area (Milani, 1975). Budget participation can be reflected on greater satisfaction with the activities and greater commitment to budget goals (Maiga, 2005), and a better performance (Derfuss, 2016; Jacomossi et al., 2018; Kren \& Liao, 1988; Lunardi et al., 2020; Mia, 1988; Nouri \& Parker, 1998; Shields \& Shields, 1998).

Although research on the influence of budget participation on performance has been going on for several decades (Stearns, 2016), by exploring these interactions (e.g., Chong \& Johnson, 2007; Dani, Zonatto, \& Diehl, 2017; Derfuss, 2016; Isgiyarta, Nugroho, Ratmono, Helmina, \& Pamungkas, 2019; Stearns, 2016) it has evidenced mixed, controversial, or inconsistent results. This suggests that this relationship may be influenced by other mental or cognitive states of individuals (Covaleski et al., 2007). This justifies the inclusion of other intervening variables (Nouri \& Parker, 1998) that can help explain the associated psychological and behavioral effects, which is the case of motivation (Baerdemaeker \& Bruggeman, 2015; Brownell \& McInnes, 1986) and the commitment to the goals (Kyj \& Parker, 2008; Nouri \& Parker, 1998; Parker \& Kyj, 2006; Wentzel, 2002), in addition to explaining the conflicting results of direct analysis of the interaction (Dani et al., 2017; Derfuss, 2016).

The issue of motivation at work is one of the psychological effects that can come from budget participation (Chong et al., 2005; Shields \& Shields, 1998). Motivation is capable of stimulating the dedication necessary to attain or achieve a goal, encouraging or boosting the employees (intrinsically or extrinsically) to work. Therefore, the motivation of employees is considered a decisive factor in organizations, and can have a positive influence on organizational performance, as it can direct individuals to act in search of achieving the goals (Locke \& Latham, 1990).

The literature on budgets shows that motivation can influence people's behavior in meeting budget targets (Stearns, 2016), and develop from the possibility of participation in the decision related to estimates of budget targets (Chong \& Johnson, 2007; Baerdemaeker $\&$ Bruggeman, 2015). And previous results suggest that motivation can act directly on efforts to make the budget (Brownell \& McInnes, 1986) and indirectly (intervening effect) (Mia, 1988). However, its motivational role between budget participation and results is inconsistent (Santos, Lavarda, \& Marcello, 2014).

The budget literature has not addressed the effects of motivation at work and its impacts on the execution of tasks (Lau \& Roopnarain, 2014), nor the motivational types of employees (Gómez-Ruiz \& Rodríguez-Rivero, 2018; Van der Kolk, Van Veen-Dirks, \& Bogt, 2018; WongOn-Wing, Guo, \& Lui, 2010). Furthermore, there are few studies on extrinsic motivation (tangible incentives), which stem from underlying stimuli (e.g., remuneration, bonuses), and intrinsic motivation (intangible incentives) achieved through non-remunerative stimuli (e.g., social recognition) (Deci \& Ryan, 1985; Kuvaas, Buch, Weibel, Dysvik, \& Nerstad, 2017). These are gaps that remain open when demonstrating the respective roles and interactions of each motivational subtype (Kuvaas et al., 2017), with participation and commitment with the budget targets.

According to Welsh, Baer, Sessions and Garud (2020), individuals committed to a goal tend to be, in general, motivated to avoid failure to achieve the goal. This is because the expected outcomes, resulting from the establishment of goals, occur through cognitive processes. This factor demonstrates the approach to cognitive processes that motivate behavior (Welsh, Baer, Sessions, \& Garud, 2020) and seek to identify which factors influence the commitment to goals, since these factors may have critical implications in their definitions (Hassel \& Cunningham, 1993).

In this context, the research question is: What are the effects of the interactions between budget participation, motivation at work (intrinsic and extrinsic), and commitment to budget goals? Thus, the study aims to smooth out the interactions between budget participation, motivation at work (intrinsic and extrinsic), and commitment to budget goals. To this end, we analyze the direct effects between the variables and the indirect effect (mediation) of motivation, as Sholihin, Pike, Mangena and Li (2011). In this study, motivation is understood as a psychological (socio-affective) aspect (Wong-On-Wing et al., 2010), capable of influencing 
behavior in relation to budget targets. The motivational effects may be due to the possibility of subordinates being able to actively participate in the budget process. In this way, both participation and motivation can directly lead to different levels of commitment to goals, since individuals can perceive this experience differently (Stearns, 2016).

Employees who could participate in the budget elaboration process may feel that their basic psychological needs, inherent to all human beings as advocated by the theory of self-determination (SDT), were met (autonomy, competence, and interconnection/relationships), (Baerdemaeker \& Bruggeman, 2015). This can generate motivation to meet their goals. This motivation can also help them behave more positively with the budget process, for example, through better acceptance and execution of the elaborated and shared budget, presenting greater commitment (Wafiroh, Abdani, \& Nurdin, 2020).

The findings of this research reveal that motivation is a multidimensional construct and that individuals can experience this state in different ways (Deci \& Ryan, 1985; Ryan \& Deci, 2000) in the face of budget engagement opportunities and the importance of goals for them (Reid, 2002). Motivation acts as a stimulus that can direct individuals to act in the direction of their goals and manifest themselves in management (Lau \& Roopnarain, 2014) from budget participation. In addition, participation per se, directly and indirectly, leads to a greater commitment to budget targets.

We contribute empirically to the flow of research on the budget process by deepening the understanding of the antecedent factors that can boost the commitment of managers to budget goals. Through a behavioral approach, the cognitive and motivational mechanisms that may be related to the employee's performance are demonstrated (Locke, Motowidlo, \& Bobko, 1986; Murray, 1990), in particular with their goals, as well as the motivational and behavioral potential tied to the budget (Argyris, 1952) and budget participation.

Furthermore, we contribute to the recent discussions of accounting that establish differences between the types of motivation to understand how the different management controls can influence the performance of employees (Baerdemaeker \& Bruggeman, 2015; Gómez-Ruiz \& Rodríguez-Rivero, 2018; Wong-On-Wing et al., 2010). For the practice of management accounting, the results contribute by highlighting the importance of individual variables (Baerdemaeker \& Bruggeman, 2015) that help understand psychological and behavioral aspects related to the budget process of managers, through the commitment to budget goals and motivation at work.

\section{THEORETICAL FOUNDATION}

\section{Budget participation}

A budget system that allows managers to participate and be responsible for the process of preparing the budget and setting goals can be positive for the organization. The literature highlights among the positive effects: increase in positive attitudes and increased performance at work (Argyris, 1952; Jacomossi et al., 2018; Lunardi et al., 2020; Mia, 1988; Nouri \& Parker, 1998), information sharing (Kyj \& Parker, 2008; Lunardi et al., 2020; Shields \& Shields, 1998), employee satisfaction (Chong et al., 2005; Kyj \& Parker, 2008; Zonatto, Nascimento, Lunardi, \& Degenhart, 2020), perception of organizational justice (Derfuss, 2009; Kyj \& Parker, 2008; Sholihin, Pike, Mangena, \& Li, 2011; Wentzel, 2002), open communication and interaction with the employee (Lavarda \& Almeida, 2013), motivation (Kyj \& Parker, 2008), and definition of budget goals (Hassel \& Cunningham, 1996; Maiga, 2005; Milani, 1975).

Although the management literature for decades has been trying to understand the conflicting results of the direct interaction of budget participation with the performance (of employees, managerial and organizational), gaps are still observed (Dani et al., 2017; Derfuss, 2016), mainly related to the identification of psychological and cognitive factors that can help explain these interactions. Moreover, it is known that other variables can act in an intervening way (Mia, 1988; Nouri \& Parker, 1998) and help better understand these relationships.

Researchers propose that the involvement of employeesindecision-makingenables agreatercommitment to the organization in which they work (Parker \& Kyj, 2006). By fostering communication between the different organizational levels and stimulating intra-organizational cooperation and communication (Brownell \& McInnes, 1986), the employee's participation in the budget process can influence the process and definition of budget goals (Hassel \& Cunningham, 1996; Maiga, 2005; Milani, 1975) and reflect more on the scope of these (Almasi, Palizdar, \& Parsian, 2015; Nouri \& Parker, 1998; Subramaniam \& Mia, 2001; Wong-On-Wing et al., 2010). In turn, greater commitment influences performance (Badu, Awaluddin, \& Mas'ud, 2019; Nouri \& Parker, 1998).

Similarly, it is recognized that there are cognitive benefits resulting from the budget participation of managers (Hassel \& Cunningham, 1993). More involvement can increase confidence and foster feelings of accomplishment, sense of personal satisfaction, sense of belonging, and greater identification with the organization (Wong-OnWing et al., 2010). When there is openness to effective communication in the organization, in addition to the 
individual acquiring improvement, he can strengthen his relations with the company. Active participation and discussions on organizational issues and decisions can lead the individual to consider himself an important member of the organization and promote feelings of self-esteem by being heard (Maiga, 2005). With this, budget participation can influence the actions of these employees (Birnberg, Luft, \& Shields, 2007) by stimulating motivation at work. As a result of increased motivation, there will also be positive performance effects.

In this research, therefore, budget participation is analyzed as being able to influence differently the individuals involved (Birnberg et al., 2007; Covaleski et al., 2007), and this may reflect on their managerial performance (Brownell \& McInnes, 1986; Jacomossi et al., 2018; Lunardi et al., 2020). From the behavioral approach (individual), we analyze how budget participation is related to individual behaviors, such as the commitment to performance linked to budget goals, and motivational stimuli, resulting from motivation at work (Brownell \& McInnes, 1986; Lau \& Buckland, 2001; Murray, 1990; Shields \& Shields, 1998).

\section{Budget participation and motivation at work}

Motivation is considered a force that induces the action of the individual, with implications in the form, direction, intensity, and duration of the behavior (Meyer, Becker, \& Vandenberghe, 2004). For Locke and Latham (2004), the motivation consists of "internal factors that drive action and external factors that can act as incentives to action" (Locke \& Latham, 2004, p. 48). These factors are called intrinsic and extrinsic motivation. According to Deci, Connell and Ryan (1989) and Vallerand (1997), intrinsic motivation is understood as that individual desire to perform an activity without requests, experiencing pleasure and satisfaction inherent to the activities and in performing them. Intrinsic motivation is related to positive organizational effects, such as work involvement, job identification, and employee productivity (Pinder, 2011). Extrinsic motivation can be understood as the desire to perform an activity with the intention of achieving a benefit (incentive, reward) or avoid a negative result (punishment) (Deci, Connell, \& Ryan, 1989; Vallerand, 1997).

The stimulus to budget participation is related to the motivational effects (Reid, 2002), for influencing allocation, direction, and persistence of their efforts at work (Birnberg et al., 2007). Budget participation promotes positive attitudes in employees, motivates them (Shields \& Shields, 1998) and allows them to actively engage in the budget and in the goals (Reid, 2002). Reid
(2002) points out that participation in fact can result in the empowerment of employees from the bottom up, due to access to information and incentives that can be used in conjunction with knowledge about the organization's fundamentals to ensure compliance with its objectives.

The results of the study by Wong-On-Wing, Guo and Lui (2010) suggest that individuals may be motivated, both intrinsically and extrinsically, to participate in the budget process. It follows that participation, in addition to effects on results and rewards, influences individual mental representations by psychological processes, such as goal setting, level of aspiration, stress, and justice (Birnberg et al., 2007).

Macinati and Rizzo (2014) report that budget participation triggers an effect due to the opportunity to participate in the budget-setting process. This improves employees' sense of control, trust, and identification with the organization. Although Mia (1989) indicated that the interactions between budget participation and motivation present divergent results (positives, negatives, significant and not significant), the participation in the budget is able to have a positive impact on the motivation of employees, increasing the quantity and quality of production and cooperation between the managers (Djalil, Indriani, \& Muttaqin, 2017).

Baerdemaeker and Bruggeman (2015) demonstrate that a higher level of budget participation increases the autonomous motivation of managers. Thus, participating in the budget preparation process can directly influence employee motivation. And it is expected that participation in the budget can provide the achievement of the basic psychological needs of employees (Deci \& Ryan, 1985). Like Van der Kolk, Van Veen-Dirks and Bogt (2019), it is expected that motivation will be fostered by a supportive environment that can: (a) evoke feelings of competence, by enabling the involvement in the budget; (b) provide a sense of autonomy, by allowing the employee to express opinions and take part in making choices; and (c) meet the needs of relationships, when being heard by their peers.

Thus, in the light of the theory of self-determination, it is recognized that managers will show improved qualities of motivation for work, as they identify with the value and importance of their work (Deci, Olafsen, \& Ryan, 2017). It is advocated that individuals, by effectively participating in the definition of goals, value participation itself and attribute feelings of achievement (intrinsic motivation). However, it is possible that employees obtain more information through communication, and that this involves offering rewards tied to their performance. This can lead the individual to attribute a different mean to these tasks, with greater emphasis on performance and 
competence (Lau \& Roopnarain, 2014). Thus, the first hypothesis is formulated:

H1: Budget participation positively influences intrinsic motivation $\left(\mathrm{H}_{1 \mathrm{a}}\right)$ and extrinsic motivation $\left(\mathrm{H}_{1 \mathrm{~b}}\right)$ at work.

\section{Motivation at work and commitment with budget targets}

Commitment is a force that unites an individual to a course of action for a specific target (Meyer \& Herscovitch, 2001). This commitment is tied to a motivational factor and can take different forms and be directed to different focuses (Meyer et al., 2004), as the commitment to the budgets. It is understood as the determination to try to reach a goal and the persistence of pursuing it over time (Chong \& Chong, 2002; Locke \& Latham, 1990).

Mathieu and Zajac (1990) highlight that the commitment to budget goals supports psychological aspects, which involve individual, professional, and organizational factors, and includes specific assessments, feelings, emotions, and trends of action for individuals under observation Kren (1992) points out that the commitment to the goals act mobilizing efforts and increases persistence in its reach. Gómez-Miñambres (2012) explain that the commitment to goals can be determined by the interaction between goals and patterns of individual references, in which higher references require high goals for employees to be more committed to the goals. Locke and Latham (2002) warn that during a commitment to goals, individuals must feel motivated.

Considering the theory of self-determination, it is suggested that individuals will exhibit certain behaviors because there is a motivation behind their behavior. Thus, different motivations will be reflected differently on the behaviors of individuals, since the motivation is due to the impulse within themselves to do something (Ryan \& Deci, 2000). Kuvaas, Buch, Weibel, Dysvik and Nerstad (2017) and Van der Kolk, Van Veen-Dirks e Bogt (2019) warn that intrinsic and extrinsic motivations demonstrate different effects on employee outcomes and should be addressed separately.

Gómez-Ruiz and Rodríguez-Rivero (2018) add that the consultative participation of employees increases autonomous motivation (close to intrinsic motivation), while pseudo-participation decreases it. Van der Kolk et al. (2019) point out that intrinsic and extrinsic motivations are positively associated with departmental performance. And that the motivations (intrinsic and extrinsic) support the relationship between management controls and performance; however, relate differently to controls and performance. This suggests that the behavior of managers in relation to their commitment to budget goals may be influenced differently by intrinsic motivation and extrinsic motivation.

The study by Ke and Zhang (2009) identified that both intrinsic and extrinsic motivation relate positively and significantly to the commitment to budget goals. Subramaniam and Mia (2001) describe that individuals' commitment to goals is related to extrinsic and intrinsic factors. Each of these elements requires actions of individuals to achieve the goals, and if they are motivated (intrinsically or extrinsically) to accomplish them, they try to accomplish it (Meyer et al., 2004).

Intrinsic motivation is capable of determining the direction of the individual's behavior, as well as the level of effort and persistence in the face of obstacles, resulting from the need for self-determination and competence (Deci \& Ryan, 1985). Intrinsic motivation encourages the individual to commit more to the goal (Ke \& Zhang, 2009). Gómez-Miñambres's (2012) study pointed out that the interactions between goals and intrinsic motivation are different from extrinsic interactions, and individuals, by worrying about setting goals and achieving them, create a sense of achievement. Thus, the following hypothesis is formulated:

H2a: Intrinsic motivation in the work acts positively on the commitment to budget goals.

According to the theory of self-determination, external incentives positively affect the commitment to goals (Deci \& Ryan, 2000). Locke and Latham (2002) point out that using external incentives can be an alternative to increase commitment to goals, since compensation relates to the employee's commitment to the organization because of advantages such as salaries and other benefits (Allen \& Meyer, 1993). With this, it is assumed that extrinsic motivation can lead individuals to work with greater intensity to get the expected rewards, such as career opportunities and financial gains (Ke \& Zhang, 2009). It is argued that extrinsic motivation can keep individuals more committed to the task, which add to the importance of doing well since the rewards will be tied to their performance (Ryan \& Deci, 2000). These arguments suggest the hypothesis:

$\mathrm{H} 2 \mathrm{~b}$ : Extrinsic motivation at work acts positively on the commitment to budget goals.

\section{Mediating role of motivation at work}

The relationship between budget participation and management performance has been widely explored in management accounting and has shown positive results 
(Argyris, 1952; Badu et al., 2019; Brownell \& McInnes, 1986; Dani et al., 2017; Derfuss, 2016; Mia, 1989; Nouri \& Parker, 1998; Rachman, 2014; Wong-On-Wing et al., 2010; Zonatto, Weber, \& Nascimento, 2019). The literature that explores budget participation also recognizes direct and positive interactions with organizational commitment (Baerdemaeker \& Bruggeman, 2015; Subramaniam \& Mia, 2001) and with the commitment to goals (Chong \& Chong, 2002; Chong \& Johnson, 2007; Chong \& Tak-Wing, 2003; Kren \& Liao, 1988; Lavarda, Sant'ana, Manfroi, \& Dagostini, 2015; Macinati \& Rizzo, 2014; Wentzel, 2002).

The goal setting theory can help explain this relationship by emphasizing the need to verify the effect of the establishment of organizational goals in the work of each employee (Locke \& Latham, 1990). It can also help explain that the greater the participation of employees in the budget process, the greater the commitment to the accomplishment of tasks and the performance of their function (Isgiyarta et al., 2019). It follows that participation can provide motivational and cognitive mechanisms (Birnberg et al., 2007; Reid, 2002), with attitudinal and behavioral effects (Maiga, 2005).

With that, one can foster the feeling of belonging (Shields \& Shields, 1998), feelings of self-valorization, influence, and involvement (motivational aspects) in budget decisions (Maiga, 2005), in addition to promoting a sense of equity (Wentzel, 2002). These factors can positively affect their commitment and achievement of budget goals (Lavarda et al., 2015). It can even lead managers to set more difficult goals (Kren \& Liao, 1988; Locke \& Latham, 1990).

Although the literature has presented evidence of several effects of budget participation in the attitudes and behavior of managers, Lau and Tan (2006) point out that these interactions are not simple. And in general, they are explained by other mediating or moderating variables (Covaleski et al., 2007; Derfuss, 2016), as motivation (Baerdemaeker \& Bruggeman, 2015; Brownell \& McInnes, 1986). Gómez-Ruiz and Rodríguez-Rivero (2018), when analyzing the effect of employee motivation, as a mediator of the relationship between consultative participation and performance, found that autonomous motivation mediates this relationship; the controlled motivation, however, does not. This suggests that the direct relationship between employee participation can be explained (indirectly) by the question of motivation.

Budget participation can trigger an increase in employees' affective commitment by valuing their interaction, as they perform an assessment with their involvement and influence on the budget target (Stearns, 2016). With this, employees may feel greater emotional bond with the organization and greater motivation to achieve their goals (Baerdemaeker \& Bruggeman, 2015). Wong-On-Wing et al. (2010) point out that employees may feel intrinsically motivated in the participation of goal setting, especially when they aim to obtain individual achievements and satisfactions as results of their actions. This motivational factor can act on the commitment to goals.

According to Subramaniam and Mia (2001), individuals' commitment to the organization's goals can direct them to receive extrinsic rewards (bonuses) and intrinsic rewards (job satisfaction and better relationships with their peers and superiors). In this research, it is assumed that both resources are distinctly stimulated by individual motivation, under the influence of the participation of budgetary processes provided to individuals. It is thus recognized that the commitment to the goals depends both on the structural level of participation offered by the organization and on the individual differences of the subordinate (Stearns, 2016). Based on the arguments, it is proposed that budget participation can stimulate the commitment to goals, and this relationship can be explained by the mediating effect of motivation at work (intrinsic and extrinsic). Thus, the third hypothesis is formulated:

H3: Budget participation, mediated by motivation at work (intrinsic and extrinsic), acts positively on the commitment to budget goals.

In this hypothesis, it is proposed that budget participation presents a motivational function, which stimulates motivation at work, both intrinsic and extrinsic, and that it is directly and indirectly reflected on the levels of dedication of managers with the budget goals. Figure 1 represents the design of this research. 


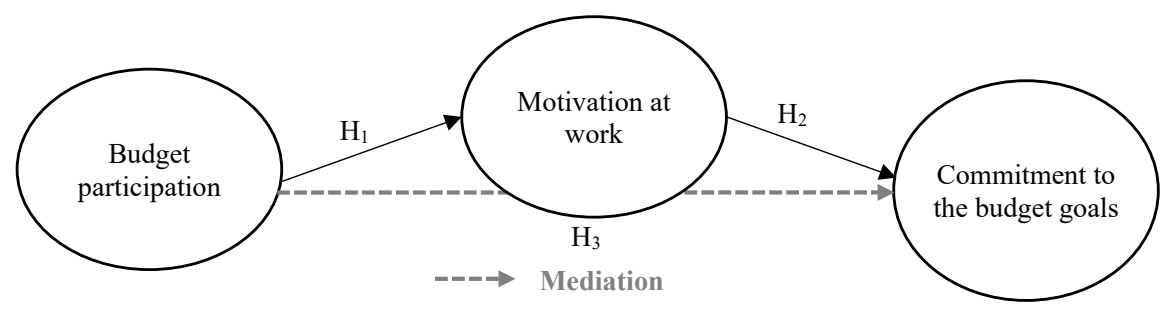

Figure 1. Theoretical model of research.

By the established hypotheses it is expected that: (a) budget participation positively influences motivation at work (intrinsically and extrinsically); (b) motivation at work positively influences (intrinsically and extrinsically) the commitment to budget goals; (c) motivation at work acts as a mediating variable between budget participation and commitment to goals.

\section{RESEARCH METHODOLOGY}

\section{Population and sample}

This study investigates the perception of middle-level managers from several functional areas, as recommended in previous studies (Brownell \& McInnes, 1986; Chong \& Tak-Wing, 2003; Hassel \& Cunningham, 1993; Mia, 1989; Mucci, Frezatti, \& Dieng, 2016). Intermediate level managers are in line positions, directly involved in the operations and daily activities of the business (Chong \& Tak-Wing, 2003) ) and are one or two levels below the board (Mucci et al., 2016), which allows for different levels of budget participation and commitment to goals.

Initially, 195 Brazilian companies from the South (90) and Southeast (105) regions were selected with Brazilian controlling interest, ranked among the 1,000 best and largest companies in Brazil in 2016, in Exame magazine's ranking (Revista Exame, 2017), according to annual net revenue. For managers who fit the profile (acting at the intermediate level) was sent the invitation to make up a network created on LinkedIn, clarifying the purpose of the research. Among the 1,400 invitations sent, an acceptance rate of $36.3 \%$ was obtained. Care and proper control of shipments and acceptances were taken so that at least three employees of each company were added, for the purpose of heterogeneity of the sample. The questionnaire link was forwarded to the 508 intermediate level managers who accepted the invitation, and 146 answered the survey.

The survey data were collected through a questionnaire in QuestionPro format and forwarded via LinkedIn, from December 2017 to March 2018. The search initially occurred from the selection of employees of the 195 companies in the sample, by the use of the terms "supervisor," "coordinator," and "manager" on the LinkedIn platform, considering the position in the selected company. Among the 195 companies, for a small number it was not possible to send the invitation to any manager, and in a reasonable number of companies, even after several attempts, no one accepted the invitation for sending the link.

The required sample size and statistical power were calculated with the aid of the G*Power software (Faul, Erdfelder, Buchner, \& Lang, 2009), considering the total effect of three predictor variables (budget participation, intrinsic motivation, extrinsic motivation) on the dependent variable (commitment to budget targets), at the significance level of $5 \%$, a statistical power of 0.95 , which indicated a minimum sample of 119 valid answers. A total of 146 responses were obtained, but 15 were excluded because they were incomplete or with equal answers in all statements, so the final sample was 131 valid answers.

The final sample consisted of 116 men (88.55\%) and 15 women $(11.45 \%)$, with the average age of 40 . About $65 \%$ have specialization and/or MBA, $10 \%$ have master's degree, and $22 \%$ have degree in accounting, administration, management, or engineering. Regarding the position held, $49 \%$ act as managers, $34 \%$ as coordinators, and $17 \%$ as supervisors. These professionals work in different functional areas, according to the recommendations of Chong and TakWing (2003), such as finance, accounting, human resources, costs, sales, and production. On average, they have been in that position for five years and have been working for approximately nine years at the same company.

The selected companies have a different size (on average, 3,300 employees) and operate in different segments. Among 131 respondents, 17 distinct economic sectors were listed, among which the participation of these sectors stood out: consumer goods or capital $(12.8 \%)$, services $(12 \%)$, energy $(11 \%)$, health services $(9.8 \%)$, pulp and paper $(6.8 \%)$, steel and metallurgy $(6 \%)$, retail $(6 \%)$, and agricultural production $(5.3 \%)$. Thus, the study minimizes the limitations of external validity, by covering very different organizations and varied operational areas, implying a greater possibility of generalizing the results of the study. 
Measurement of variables and construct of the research

The measuring instruments of the constructs used a seven-point Likert scale (Appendix A) and asked respondents to indicate for each statement: their perception of their level of budget participation (between $1=$ very low and $7=$ very high); their motivation in the performance of the tasks of their work (between $1=$ totally disagree and $7=$ totally agree); and the degree of agreement with the statements in relation to their commitment to the budget goals of their organization (between 1 = totally disagree and $7=$ totally agree). A pre-test was performed with three researchers in the area and three professionals, in order to verify inconsistencies and the interpretation of each of the statements. Revisions to the essay were made before making the questionnaire available at the QuestionPro platform.

The construct budget participation was adapted from the instrument of Hassel and Cunningham (1993), validated by Milani (1975), and has been used by other researchers in the area (e.g., Maiga, 2005). This instrument is made up of six statements and presents a Cronbach's alpha of 0.889 . Exploratory factor analysis (EFS) presented a KMO of 0.855 and an explained total variance (VTE) of $64.93 \%$. Motivation at work was based on the study by Kuvaas et al. (2017) for including the budget context and adopting a validated approach in the management area, with two-dimensional motivation constructs (intrinsic and extrinsic) (e.g., Van der Kolk et al., 2019).

Thus, motivation was measured by 10 statements (6 referring to the intrinsic motivation dimension and 4 referring to the extrinsic motivation dimension). In the EFA, the constructs were grouped into two factors (intrinsic and extrinsic), as theoretically pointed out, and present together a KMO of 0.743 and a VTE of $69.67 \%$. To validate the constructs according to theoretical determination, two statements of intrinsic motivation (MINTR1; MINTR3) and one of extrinsic motivation (MEXTR2) were excluded. Intrinsic motivation indicated reliability of $0.857, \mathrm{KMO}$ of 0.788 , and VTE of $71.83 \%$, while extrinsic motivation indicated reliability of $0.732, \mathrm{KMO}$ of 0.686 , and VTE of $65.60 \%$.

The construct commitment to the budget goals was measured by the reference instrument to the budget area, proposed by Chong and Chong (2002), ), composed of four statements, being reverse CMO4. An assertive was excluded in the EFA (CMO4). After exclusion, this construct presented a Cronbach's alpha of 0.692, $\mathrm{KMO}$ of 0.667 , and total explained variance of $63.72 \%$.
Control variables (gender, age, schooling, position, area of business, time in the position, and sector) were added to the model to verify the correlation with the other constructs and their effects on the dependent variable. Although some of these variables presented significant correlations with constructs in the measurement model, their inclusion in the structural model did not influence the results and path coefficients.

\section{Data analysis procedures}

Non-response bias tests were performed to validate the information obtained by the research instruments. First, the first last method was adopted (comparison of the means of the first 10 with the last 10 responses) and there were no statistically significant differences in any construct (p-values between 0.1204 and 0.609). The same occurred when analyzing the mean of the initial responses with the final scans ( $\mathrm{p}$-values between 0.253 and 0.592). Subsequently, reliability and AFE tests were performed, with analysis of the common bias method, by the Harman's single factor test. The total variance explained for a single factor was $68.03 \%$, which discards the common method trend and suggests that the instruments did not introduce variations in responses or noise in data or in their theoretical and statistical inferences (Podsakoff, MacKenzie, Lee, \& Podsakoff, 2003).

Data analysis was assisted by SPSS for exploratory and descriptive data analysis and Smarth-PLS for structural equation modeling (SEM). This technique is used to analyze the data and test the hypotheses, estimated from the partial least squares (PLS). It makes it possible to estimate a series of separate but interdependent multiple regression equations simultaneously by specifying the structural model (Hair, Hult, Ringle, \& Sarstedt, 2014).

The modeling of structural equations aims to examine the structure in the interrelations between the constructs of the analysis, which combines the use of multivariate methods of factor analysis and multiple regression analysis (Hair, Anderson, Tatham, \& Black, 2009). The use of Smarth-PLS in SEM is based on a set of nonparametric evaluation criteria, using procedures such as bootstrapping and blindfolding to evaluate the model of measurement of construct measurements (convergent and discriminant validity and internal and composite reliability) and the structural model (size and significance of path coefficients), predictive validity of the model $\left[R^{2}\right]$, rpredictive relevance $\left[Q^{2}\right]$ and effect sizes $\left[\mathrm{F}^{2}\right]$ ) (Hair et al., 2014). 
In the analysis, mediation tests were also performed, considering that mediation can be understood as a mechanism by which the independent variable influences the dependent variable, through the transmission of effects of the mediating variable (Baron \& Kenny, 1986). Hayes (2013) emphasizes that the mediating variable acts to demonstrate evidence or test hypotheses about procedures that explain the occurrence of certain effects, or under what conditions they act as facilitators or inhibitors of such effects. In addition to following the recommendations of Baron and Kenny (1986), mediations were confirmed by bootstrapping analyses, with 5,000 interactions (Smart-PLS), which helps test mediation hypotheses through a rigorous test of indirect effects, evaluating and comparing indirect effects in mediator models (Hayes, 2013).

\section{ANALYSIS OF RESULTS}

\section{Measurement model}

The measurement model demonstrated that all constructs have average variance extracted (AVE) greater than 0.5 (Hair et al., 2009). The reliability tests (internal and composite) also attested that the responses of the sample are reliable and do not contain biases; all constructs are higher than 0.70 (Hair et al., 2014). To test the discriminant validity, the Chin (1998) cross-loading criteria (Appendix A) and the criterion recommended by Fornell and Larcker (1981) (Table 1) were evaluated. In both tests, the strength of each construct was verified in differentiating from the other ones and capturing exclusive phenomena in the proposed model. The square root of each AVE (diagonal, Table 1) presents a greater explanation in its own construct than the values referring to the correlations between the other constructs, with values higher than 0.7.

Table 1. Validity of the measurement model.

\begin{tabular}{|c|c|c|c|c|c|c|c|c|c|c|c|c|}
\hline Description & 1 & 2 & 3 & 4 & 5 & 6 & 7 & 8 & 9 & 10 & 11 & 12 \\
\hline 1 Budget participation & 0.805 & & & & & & & & & & & \\
\hline 2 Intrinsic motivation & 0.470 & 0.847 & & & & & & & & & & \\
\hline 3 Extrinsic motivation & -0.191 & -0.049 & 0.799 & & & & & & & & & \\
\hline 4 Commitment to goals & 0.436 & 0.460 & -0.178 & 0.798 & & & & & & & & \\
\hline 5 Age & 0.111 & 0.217 & -0.233 & 0.111 & 1 & & & & & & & \\
\hline 6 Gender & 0.021 & -0.049 & -0.002 & 0.079 & 0.143 & 1 & & & & & & \\
\hline 7 Schooling & 0.089 & 0.161 & -0.153 & 0.153 & 0.132 & -0.048 & 1 & & & & & \\
\hline 8 Charge & 0.328 & 0.188 & 0.127 & 0.138 & 0.257 & 0.123 & 0.260 & 1 & & & & \\
\hline 9 Time in office & 0.110 & 0.047 & 0.042 & 0.050 & 0.428 & 0.166 & 0.101 & -0.139 & 1 & & & \\
\hline 10 Time in the company & 0.173 & 0.202 & 0.094 & 0.110 & 0.285 & 0.087 & -0.102 & 0.044 & 0.562 & 1 & & \\
\hline 11 Area & 0.168 & 0.081 & -0.076 & -0.010 & -0.049 & 0.119 & 0.114 & -0.083 & 0.065 & 0.118 & 1 & \\
\hline 12 Sector & 0.084 & 0.031 & -0.010 & -0.045 & -0.119 & -0.165 & 0.070 & -0.070 & -0.109 & -0.105 & 0.131 & 1 \\
\hline
\end{tabular}

Note. $\mathrm{N}=131$. This table demonstrates the validity of the measurement model, through discriminant validity and correlations between research constructs. The factors 1 to 4 refer to the constructs of the research, and the factors 5 to 12 to control variables. Elements on diagonal represent the square roots of the AVE. Elements outside the diagonal represent the correlations between constructs. P-value correlations $\mathrm{p}<0.05$ (two ends) refer to values greater than $|0,173|$; and $\mathrm{p}<0.01$ (two ends) refer to values greater than $|0,233|$.

It is observed that budget participation interacts positively with intrinsic motivation $(\beta 0.470, \mathrm{p}<0.01)$ and commitment to budget targets $(\beta 0.436, \mathrm{p}<0.01)$, and negatively with intrinsic motivation $(\beta-0.191, \mathrm{p}<$ $0.05)$. Similarly, commitment to budget targets interacts positively with intrinsic motivation $(\beta 0.460, \mathrm{p}<0.01)$ and negatively with extrinsic motivation $(\beta-0.178$, $\mathrm{p}<0.05)$. This suggests that participation may be an antecedent that psychologically stimulates individuals but may not influence or even discourage attitudes that prioritize results and/or financial benefits. Moreover, it is believed that a greater commitment to the results may be due to greater intrinsic than extrinsic stimulus, while the latter may misstate the focus of its objectives and its effective scope. 
A few control variables showed significant correlations, such as: (a) the age of the manager, which correlates positively with intrinsic motivation $(0.217, \mathrm{p}<0.05)$ and negatively with extrinsic motivation $(-0.233, \mathrm{p}<0.01)$, which may indicate that older individuals have a greater need for intrinsic motivation and lower need for extrinsic motivation (remuneration, returns on performance); (b) position level of manager with budget participation $(0.328$, $\mathrm{p}<0.01)$ and intrinsic motivation $(0.188, \mathrm{p}<0.05)$, which may indicate that higher positions, such as area managers, have higher budget participation and higher levels of intrinsic motivation in the performance of their duties; and (c) the company time of these managers with their level of budget participation $(0.173, p<0.05)$ and intrinsic motivation $(0.202, \mathrm{p}<0.05)$, factors that may suggest that more company time may induce greater involvement with budgets and intrinsic feelings.

The variance inflation factor (VIF) measurements, which assess the existence of collinearity between the variables, revealed that all indicators are lower than five, and the external IVF varied between 1.373 and 3.588, and the internal FIV between 1 and 1.332. The fit model, which indicates the adjustment of the model, presented a SRMR (standardized residual mean square root) of 0.076 , with a chi-square of 274.529 and a NFI of 0.751 , which suggests that the hypothetical structure of the model fits the empirical data. Thus, following the assumptions suggested by Hair et al. (2009), the presence of associations between the variables was verified, the constructs are validated, and the validity of the measurement model is attested. Thus, we proceed to the evaluation of the structural model.

\section{Structural model}

The analysis of the structural model seeks to verify the statistical validity and confirm the adequacy of the measurement model, attesting to the significance of the relationships between the constructs of the study and the confirmation of hypotheses. Table 2 shows the results of the path, $\mathrm{t}$-value, $\mathrm{p}$-value $\mathrm{F}^{2}$ and $\mathrm{R}^{2}$ tests.

Table 2. Structural model analysis.

\begin{tabular}{clccccc}
\hline Chance & \multicolumn{1}{c}{ Path } & Mr. Coef. & DP & T-value & $\mathrm{F}^{2}$ & $\mathrm{R}^{2}$ \\
\hline $\mathrm{H}_{1 \mathrm{a}}$ & Budget participation $\rightarrow$ Intrinsic motivation & 0.470 & 0.088 & $5.342^{* * *}$ & 0.284 & 0.221 \\
$\mathrm{H}_{1 \mathrm{~b}}$ & Budget participation $\rightarrow$ Extrinsic motivation & -0.191 & 0.099 & $1.934^{*}$ & 0.038 & 0.037 \\
$\mathrm{H}_{2 \mathrm{a}}$ & Intrinsic motivation $\rightarrow$ Commitment to goals & 0.333 & 0.079 & $4.214^{* * *}$ & 0.121 \\
$\mathrm{H}_{2 \mathrm{~b}}$ & Extrinsic motivation $\rightarrow$ Commitment to goals & -0.112 & 0.101 & 1.113 & 0.017 \\
$\mathrm{H}_{3 \mathrm{a}}$ & $\begin{array}{l}\text { Budget participation } \rightarrow \text { Intrinsic motivation } \rightarrow \\
\mathrm{H}_{3 \mathrm{~b}}\end{array}$ & $\begin{array}{l}\text { Commitment to goals } \\
\text { Budget Participation } \rightarrow \text { Extrinsic motivation } \rightarrow\end{array}$ & 0.157 & 0.044 & $3.571^{* * *}$ & 0.285 \\
\hline
\end{tabular}

Note. $\mathrm{N}=131$. This table demonstrates the analysis of the structural model (path, $\mathrm{t}$-value, $\mathrm{p}$-value $\mathrm{F}^{2}$ and $\mathrm{R}^{2}$ ) for the relationships proposed in this research and their hypotheses. The tests were carried out via bootstrapping, through two-tailed tests, significance of $95 \%$ (bias-corrected and accelerated), with 5,000 interactions. Significant relations ( $\mathrm{p}$-value) ${ }^{*} \mathrm{p}<0.05 ;{ }^{* *} \mathrm{p}<0.01 ;{ }^{* * *} \mathrm{p}<0.000$.

Table 2 shows that hypothesis $\mathrm{H}_{1 \mathrm{a}}$, which provided for the relationship between budget participation and intrinsic motivation $(\beta 0.470, \mathrm{p}<0.000)$, can be accepted, as well as $\mathrm{H}_{1 \mathrm{~b}}$, which provided for an association between budget participation and extrinsic motivation $(\beta-0.191, \mathrm{p}<$ $0.05)$, but this relation is negative. These results are aligned with previous discussions, which include the association of budget participation with motivational effects (Birnberg et al., 2007). It is argued that the participation of individuals in budget planning motivates them to act on their own to achieve the goals and that the greater the possibilities of engaging in the budget, the smaller their search for extrinsic motivations (bonuses, awards, rewards).
The intrinsic motivation presented a positive and significant relationship with the commitment to budget targets $(\beta$ 0.333, $\mathrm{p}<0.000)$, which allows confirming $\mathrm{H}_{2 \mathrm{a}}$. This result reinforces that greater involvement of individuals may be tied to positive effects on organizational results (Pinder, 2011). The hypothesis $\mathrm{H}_{2 \mathrm{~b}}$, which predicted an association between extrinsic motivation and commitment to budget goals, presents a negative and nonsignificant relationship $(\beta-0.112)$ between the variables. This suggests that paying incentives are not enough to ensure a commitment to budget goals.

Although the control variables age, manager's position level, and company time presented significant 
correlations with the constructs (Table 1), by including them in the structural model, no significant effects were observed $(\mathrm{p}>0.10)$ on the dependent variable. As a result, they are not represented in this analysis and are not included in Table 2.

Positive and significant relationship between budget participation and commitment to budget targets has been confirmed $(\beta 0.436, p<0.000)$. This result, as evidenced in previous studies (Chong \& Chong, 2002; Lavarda et al., 2015; Shields \& Shields, 1998; Sholihin et al., 2011), indicates that individuals, when they could get involved and influence the process of choices, are more stimulated to achieve the goals, because they feel responsible for the results achieved. This significant direct effect between the independent (VI - Budget participation) and dependent variables (VD - Commitment to budget goals) allows the mediation tests (Baron \& Kenny, 1986).

With the inclusion of mediating variables, there is a total of 0.178 indirect effects $(p<0.000)$, which suggests that motivation at work can help better explain the interaction between these variables (Hayes, 2013). In addition, the total effect $\left(c^{\prime}\right)$ is reduced $(\beta 0.257, \mathrm{p}<0.01)$ with the inclusion of these variables, as illustrated in Figure 2. This allows us to affirm that motivation at work partially measures the interactions between the participation of the budget and the commitment to the budget goals. In particular, the result reveals that intrinsic motivation plays a virtually exclusive role in these interactions $(\beta 0.157, \mathrm{p}$ $<0.000$ ), since extrinsic motivation seems not to be able to act as an intervener between these two variables. This partially confirmed $\mathrm{H}_{3 a}$.

$\mathrm{F}^{2}$ extracted via bootstrapping from the interactions between constructs reveals that budget participation and intrinsic motivation have an average effect size (between 0.15 and 0.35 ) under the dependent variable (Hair et al., 2014). The other interactions have a small effect (between 0.02 and 0.15$). \mathrm{F}^{2}$ testing on the blindfolding platform shows that intrinsic motivation presents a small effect size (0.14), commitment to goals has an average effect (0.15), and extrinsic motivation did not score.

The $\mathrm{Q}^{2}$ test evaluates how close the model is to what was expected of it in the prediction of the model. The values should be greater than zero and a perfect model would have a $\mathrm{Q}^{2}=1$ (Hair et al., 2014). The following values were found for each construct: budget participation 0.479 , intrinsic motivation 0.502 , extrinsic motivation 0.281 , and commitment to budget goals 0.281 . This indicates that there is conformity in the fitted model. Figure 2 shows a synthesis of the main effects evidenced by the coefficients of paths, significance, and $\mathrm{R}^{2}$.

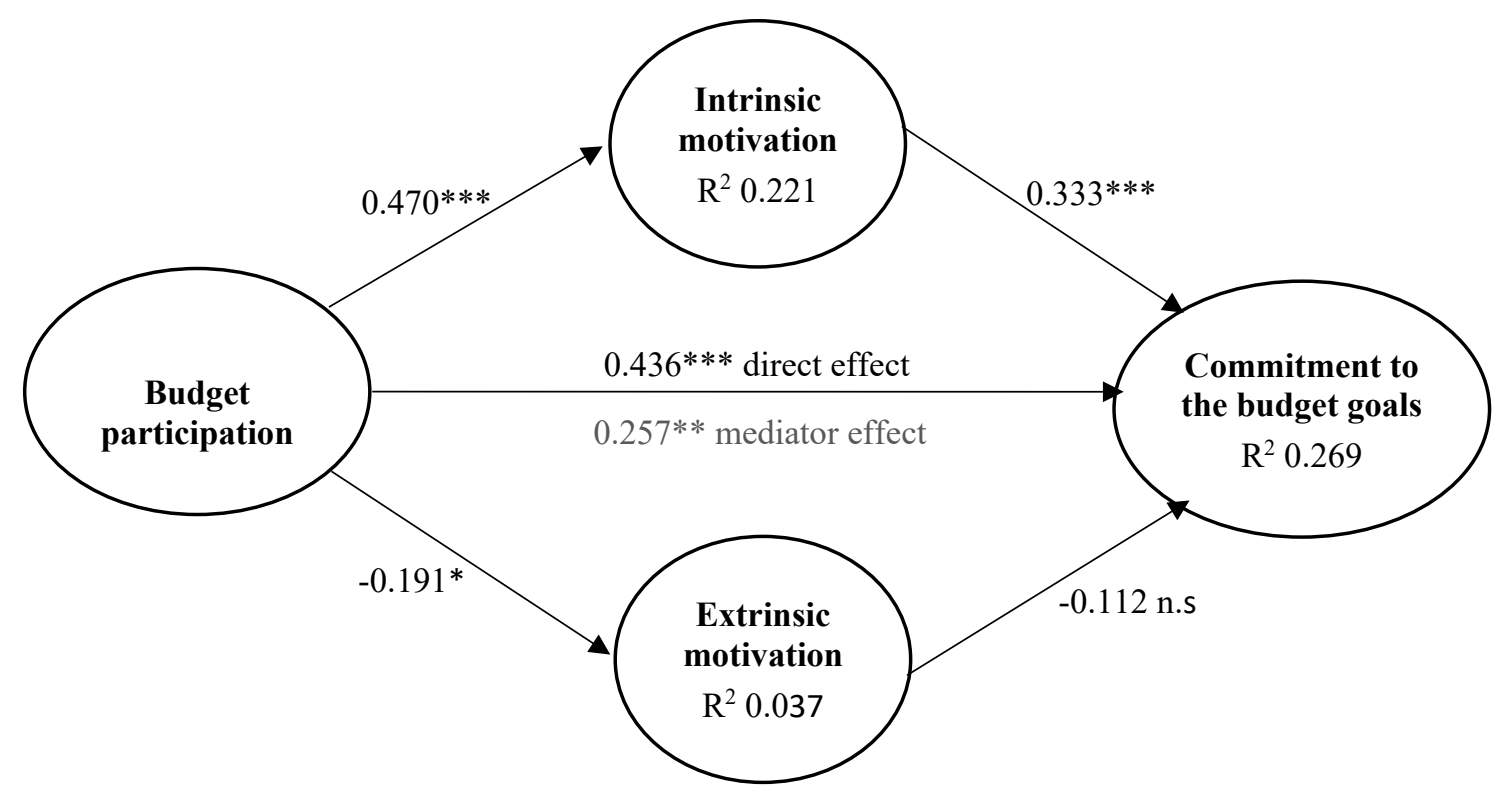

Figure 2. Structural model and its interactions.

$\mathrm{N}=131$. Significance ( $\mathrm{p}$-value) at the level of ${ }^{*} \mathrm{p}<0.05$; $^{* *} \mathrm{p}<0.01$; $^{* *} \mathrm{p}<0.000$. The mediating effect is due to the c' effect of VI $\rightarrow \mathrm{VD}$ under the influence of the mediating variable (motivation at work), the other interactions (path) correspond to direct relationships. 
According to Figure 2 and Table 2, extrinsic motivation showed a low Pearson's correlation coefficient $\left(\mathrm{R}^{2}\right)(3,7 \%)$, intrinsic motivation showed an average $\mathrm{R}^{2}(22 \%)$ and the commitment to budget targets has a big effect (27\%) (Cohen, 1988). Thus, it is inferred that extrinsic motivation alone cannot be considered the best predictor to explain interactions between variables. The intrinsic motivation, on the other hand, besides showing positive and significant direct relationships with budget participation and commitment to budget goals, also acts as a mediating variable (indirect effects) between these two variables, because its inclusion in the model reduces the direct effect between the variables, as shown in Figure 2 (without mediation $\beta 0.436, \mathrm{p}<0.000$; with mediation $\beta 0.257, \mathrm{p}<0.01)$.

\section{Discussion of results}

The results of this research reveal that by providing greater involvement of managers in defining their budgets and by allowing them to provide and receive information regarding the budgetary process, organizations face positive consequences on individual and managerial performance, both psychologically, through motivational stimulation (mainly intrinsic), and behavioral, due to greater commitment to budget goals. In general, budget participation, by enabling the expression and expanding communication (opinions, suggestions, forecasts) between the different organizational levels, in addition to contributions to the budgeting process, will influence the implementation, so that there will be greater effort toward the achievement of the goals.

The relationship between budget participation and intrinsic motivation was confirmed Baerdemaeker and Bruggeman (2015) and Djalil, Indriani and Muttaqin (2017) and indicates that the opportunity of individuals to be heard by the knowledge and/or experience acquired in their activities permits and connects them to the process itself and not to results (Vallerand, 1997). Budget participation seems to favor feelings of accomplishment, sense of personal satisfaction, and a sense of belonging and greater organizational identification (Wong-On-Wing et al., 2010). ). Depending on the theory of the self-determination, budget participation provides an environment to support the basic psychological needs of individuals, and provides greater intrinsic motivation (Van der Kolk et al., 2019).

The results between budget participation and extrinsic motivation $\left(\mathrm{H}_{1 \mathrm{~b}}\right)$ indicated negative and significant relationships. This indicates that by increasing the level of budget participation, the level of extrinsic motivation needs for performing the work is reduced. Groen, Wouters and Wilderom (2017) noted that those employees who have interesting tasks can express autonomous motivation (including intrinsic motivation) to perform the tasks that are expected of them. This would require that there be incentives arising from external incentives for performance, since people may feel less autonomous when they perceive incentives as elements that act as oppressors and controllers (e.g., monetary rewards). Therefore, the individual getting involved and participating in the budget process provides greater autonomy and self-determination and, with this, aspects focused on extrinsic motivation would be reduced, as well as the expectations of favorable resources inherent to the activities (Ryan \& Deci, 2000).

Intrinsic motivation at work proved to be significant in explaining interactions with the commitment to goals $\left(\mathrm{H}_{2 \mathrm{a}}\right)$. It is speculated that the intrinsic motivational factor can act more incisively in the commitment to goals, because individual fulfillment and satisfaction stem from the achievement of a goal (Wong-On-Wing et al., 2010), and achieving a goal can act as a psychological reward enjoyed by the individual, regardless of salary (Gómez-Miñambres, 2012).

The evidence did not confirm that the extrinsic motivation of managers is sufficient factor to increase the commitment to goals $\left(\mathrm{H}_{2 \mathrm{~b}}\right)$, as occurred in the study by Lavarda, Sant'Ana, Manfroi and Dagostini (2015), in which officials aware that they would receive a monetary contribution (measure of extrinsic motivation) had greater acceptance and commitment to the goals. These may signal that intermediate managers, due to their positions, age, and company time (variables significantly correlated with intrinsic motivation), may be more attracted or prone to intrinsic stimuli/rewards than to extrinsic stimuli/ rewards, as one might assume (Van der Kolk et al., 2019). It is important to emphasize that this evidence may be particularly important to the sample studied; therefore, it deserves further investigation.

The relationship between budget participation and commitment to budget goals, besides being significant and corroborated by the previous literature (Lavarda et al., 2015; Macinati \& Rizzo, 2014), confirms to also be influenced indirectly (through mediation) by motivation at work $\left(\mathrm{H}_{3}\right)$. It is also clear that budget participation can trigger motivational effect (Maiga, 2005) and has a positive impact on efforts with budget goals (Lavarda et al., 2015). This indicates that employees may feel a greater emotional bond with the organization when their budget participation is valued and will feel intrinsically motivated to achieve the performance goals expected by the organization (Allen \& Meyer, 1993). According to the theory of self-determination, by allowing them to have contact with information related to the budget preparation and be able to act in the communication/discussion and to express opinions, this may be reflected on decisions that will 
affect the performance of the organization. Similarly, the relationship needs can be met by the social interaction that occurs during the budget participation process, providing greater intrinsic motivation and, consequently, reflecting on the employee's work performance (Deci et al., 1989).

However, this motivational effect refers only to intrinsic motivation, since extrinsic motivation does not significantly influence the direct relationship between participation and commitment to budget goals. This allows us to partially accept $\mathrm{H}_{3}$. These results suggest that budget participation can be considered a more complex variable than previously thought (Stearns, 2016). It may, in addition to reflecting on more positive behaviors, such as a commitment to budget goals (Maiga, 2005), be able to more effectively stimulate the intrinsic motivation of employees. Allowing discussions and involvement in the budget breeds feelings of influence and contributions in the budget and final goals (Milani, 1975), which can lead to increased affective commitment of managers (intrinsic motivational effect).

In general, the results of the research reveal that the increase in budget participation perceived by employees will result in increased motivation to achieve the budget's goals, by involving individuals, who exhibit higher levels of motivation (intrinsic) and, consequently, will tend to contribute positively to the increase in individual and company performance (Stearns, 2016). In turn, the search for extrinsic returns can take place in the background when faced with the psychological mobilizations resulting from budgetary participation.

The evidence of this research corroborates those of Isgiyarta, Nugrobo, Ratmono, Helmina and Pamungkas (2019). The authors point out that participation in the budget is a means of assessing the achievement of the organizational goals of each manager, and greater employee involvement in the process of preparing the budget will encourage their motivation to successfully complete the task, obtain rewards, have more responsibility at work, and avoid job dissatisfaction (intrinsic elements). It is known that intrinsic motivation is difficult to activate (Van der Kolk et al., 2019), that the commitment to goals represents a desirable result (Welsh et al., 2020), and that budget participation configures an important antecedent variable in addressing the cognitive process related to employee and managerial performance.

\section{Implications of the study}

The evidence of this research contributes to the discussions on the implications of increased budget participation in the performance of managers. It reveals that the participation and involvement of employees in the development of performance metrics (budget targets) are important to improve the quality of these (Groen, Wouters, \& Wilderom, 2017), through the behavior of those who are more committed to the goals. Furthermore, stimuli to the intrinsic motivational effects resulting from the budget process reinforce the psychological and cognitive effects of employees who will get involved, communicate, and express their opinions about the budget process.

Empirically, it has been demonstrated that the commitment to budget goals, in addition to being directly influenced by the individual's intrinsic motivation (the desire to choose to do for the pleasure it offers) and by the possibility for the individual to participate in the budget process, can be indirectly explained by motivational factors. This finding reinforces the arguments that the individual's participation in the budget process can lead to an affective commitment to the objective (Meyer et al., 2004), whether to better accept the commitment to the budget (Shields \& Shields, 1998), or assisting in setting higher targets and increasing performance (Locke \& Latham, 2002). It may also reinforce a smaller search for extrinsic factors (Groen et al., 2017), to the extent that they feel their basic psychological needs met, fostering the intrinsic aspects.

Thus, the findings of this research are consistent with the arguments of the theory of determination of goals, referred to by Locke and Latham (1990), that the budgetary participation of individuals can increase the commitment to goals. Moreover, with the arguments associated with Ryan and Deci's (2000) theory of self-determination, they attest that individual motivations are multidimensional constructs oriented and determined by contexts that substantiate their psychological needs with different manifestations.

From a practical point of view, this study presumes that companies need to ensure that managers participate and engage in budget processes to obtain more positive individual performance at work. Superiors need to understand the benefits they can receive by providing opportunities to expand the budget participation of their subordinates, recognizing their direct and indirect implications, which include the behavioral (commitment) and motivational (especially intrinsic) scopes.

\section{FINAL CONSIDERATIONS}

This study analyzed the interactions between budget participation, motivation at work (intrinsic and extrinsic), and commitment to budget goals. The results indicated that both budget participation and commitment to budget goals are positively associated to intrinsic motivation and negatively associated to extrinsic motivation. Budget participation, in addition to directly affecting the commitment to budget goals, has this interaction mediated by intrinsic motivation. 
This suggests that giving intermediate managers greater participation and involvement in the budget process generates positive feelings, such as greater intrinsic motivation and identification with budget goals. Budget participation also seems to be able to reduce the search for extrinsic motivation but does not directly influence the commitment to budget targets, which deserves further investigation.

Because it is a cross-sectional research, it is important to have reservations about the generalization capacity of the results, since it focused only on managers at intermediate levels. With this, the research may be subject to limitations of common method bias, self-assessment and participants' response rates, and halo effect, although tests were performed to verify the trend of these elements and the results did not indicate a common method trend. In addition, the answers validated the information obtained in the research instruments by the non-response bias tests. Additionally, other methodological precautions, such as the use of instruments that allow the measurement in different multidimensional scales (different instruments), make selfassessments less susceptible to the halo effect. Reliability and multicollinearity tests also indicated that the answers can be considered consistent and adequate for theoretical and

\section{REFERENCES}

Allen, N. J. \& Meyer, J. P. (1993). Organizational commitment: Evidence of career stage effects? Journal of Business Research, 26(1), 49-61. https://doi.org/10.1016/0148-2963(93)90042-N

Almasi, H., Palizdar, M. R., \& Parsian, H. (2015). Budgetary participation and managerial performance: The impact of information and environmental volatility. Management Science Letters, 5(9), 843-854. https://doi.org/10.5267/j.msl.2015.7.001

Argyris, C. (1952). The impact of budgets on people. In R. Ashton (Ed.), The evolution of behavioral accounting research (RLE accounting). New York: Controllership Foundation.

Badu, I, Awaluddin, I., \& Mas'ud, A. (2019). Pengaruh partisipasi penyusunan anggaran, komitmen organisasi, profesionalisme, gaya kepemimpinan dan struktur organisasi terhadap kinerja managerial. Jurnal Progres Ekonomi Pembangunan, 4(1), 99-113. Retrieved from http://ojs.uho.ac.id/index.php/JPEP/article/view/6247 statistical inferences, since the constructs presented internal and external validity.

This study was limited to investigating the background of the commitment to budget goals from the perspective of the individuals involved in this process; therefore, future studies could investigate antecedents of budget participation (Shields \& Shields, 1998). Similarly, the consequential commitment to the goals could be explored in future research, such as task performance and the manager's performance. The inclusion of other elements (antecedents and consequences) can contribute to a better understanding the interactions between motivations, mainly extrinsic motivation. Although associations of commitment to goals are suggested, no support was found for these relationships. Future studies may explore psychological effects (attention, effort, and persistence) related to the difficulty linked to the goal. These studies can analyze both causality and bidirectional relationships (Nouri \& Kyj, 2008). Finally, future research may investigate possible dysfunctional behaviors (negative effect) linked to budget control, as, for example, creation of budget slack and overestimating costs and sales in the process of preparing budgets.
Baerdemaeker, J. D., \& Bruggeman, W. (2015). The impact of participation in strategic planning on managers' creation of budgetary slack: The mediating role of autonomous motivation and affective organizational commitment. Management Accounting Research, 29(1), 1-12. http://doi.org/10.1016/j.mar.2015.06.002

Baron, R. M., \& Kenny, D. A. (1986). The moderator-mediator variable distinction in social psychological research: Conceptual, strategic, and statistical considerations. Journal of Personality and Social Psychology, 51(6), 11731182. https://doi.org/10.1037//0022-3514.51.6.1173

Birnberg, J. G., Luft, J., \& Shields, M. D. (2007). Psychology theory in management accounting research. In C. S. Chapman, A. G. Hopwood, M. D. Shields (Eds.), Handbook of management accounting research (Chap. 1.03). Amsterdam: Elsevier. 
Brownell, P., \& McInnes, M. (1986). Budgetary participation, motivation, and managerial performance. The Accounting Review, 61(4), 587-600. Retrieved from https://www.jstor.org/stable/247359

Chin, W. W. (1998). The partial least squares approach for structural equation modeling. In G. A. Marcoulides (Ed.), Methodology for business and management: Modern methods for business research (pp. 295-336). Hillsdale, NJ: Lawrence Erlbaum Associates.

Chong, V. K., \& Chong, K. M. (2002). Budget goal commitment and informational effects of budget participation on performance: A structural equation modeling approach. Behavioral Research in Accounting, 14(1), 65-86. https://doi.org/10.2308/bria.2002.14.1.65

Chong, V. K., Eggleton, I., \& Leong, M. (2005). The impact of market competition and budgetary participation on performance and job satisfaction: A research note. The British Accounting Review, 37(1), 115-133. https://doi.org/10.1016/j.bar.2004.06.007

Chong, V. K, \& Johnson, D. M. (2007). Testing a model of the antecedents and consequences of budgetary participation on job performance. Accounting and Business Research, 37(1), 3-19. https://doi.org/10.1080/00014788.2007.9730055

Chong, V. K., \& Tak-Wing, S. L. (2003). Testing a model of the motivational role of budgetary participation on job performance: A goal setting theory analysis. Asian Review of Accounting, 11(1), 1-17. https://doi.org/10.1108/eb060760

Cohen, J. (1988). Statistical power analysis for the behavioral sciences (2 ed.). Hillsdale, NJ: Lawrence Erlbaum Associates.

Covaleski, M., Evans III, J. H., Luft, J., \& Shields, M. D. (2007). Budgeting research: Three theoretical perspectives and criteria for selective integration. In C. S. Chapman, A. G. Hopwood, M. D. Shields (Eds.), Handbook of management accounting research (Chap. 6, pp. 587-624). Amsterdam: Elsevier.

Dani, A. C., Zonatto, V. C. S., \& Diehl, C. A. (2017). Participação orçamentária e desempenho gerencial: Uma meta-análise das relaçóes encontradas em pesquisas desenvolvidas na área comportamental da contabilidade. Advances in Scientific and Applied Accounting, 10(1), 54-72. https://doi.org/10.14392/ASAA.2017100104

Deci, E. L., Connell, J. P., \& Ryan, R. M. (1989). Self-determination in a work organization. Journal of Applied Psychology, 74(4), 580-590. https://doi.org/10.1037/0021-9010.74.4.580

Deci, E. L., Olafsen, A. H., \& Ryan, R. M. (2017). Selfdetermination theory in work organizations: The state of a science. Annual Review of Organizational Psychology and Organizational Behavior, 4, 19-43. https://doi.org/10.1146/annurev-orgpsych-032516-113108

Deci, E. L., \& Ryan, R. M. (1985). Intrinsic motivation and selfdetermination in human behavior. New York: Springer.

Deci, E. L., \& Ryan, R. M. (2000). The "what" and "why" of goal pursuits: Human needs and the self-determination of behavior. Psychology Inquiry, 11(4), 227-268. https://doi.org/10.1207/S15327965PLI1104 01
Derfuss, K. (2009). The relationship of budgetary participation and reliance on accounting performance measures with individual-level consequent variables: A metaanalysis. European Accounting Review, 18(2), 203-239. http://doi.org/10.1080/09638180802652371

Derfuss, K. (2016). Reconsidering the participative budgetingperformance relation: A meta-analysis regarding the impact of level of analysis, sample selection, measurement, and industry influences. The British Accounting Review, 48(1), 17-37. https://doi.org/10.1016/j.bar.2015.07.001

Djalil, M.A., Indriani, M., \& Muttaqin, M. (2017). The influence of organizational commitment and motivation in the relationship between budget participation and managerial performance (empirical study on provincial government agencies (SKPA) of Aceh province, Indonesia), Brand Research in Accounting, Negotiation, and Distribution, 8, 12-24. Retrieved from https://www.edusoft.ro/brain/ index.php/brand/article/view/683

Faul, F., Erdfelder, E., Buchner, A., \& Lang, A.-G. (2009). Statistical power analyses using $\mathrm{G}^{*}$ Power 3.1: Tests for correlation and regression analyses. Behavior Research Methods, 41(4), 1149-1160. https://doi.org/10.3758/BRM.41.4.1149

Fornell, C., \& Larcker, D. F. (1981). Evaluating structural equation models with unobservable variables and measurement error. Journal of Marketing Research, 18(1), 39-50. https://doi.org/10.2307/3151312

Frezatti, F. (2009). Orçamento empresarial (5 ed.). São Paulo: Atlas.

Gómez-Miñambres, J. (2012). Motivation through goal setting. Journal of Economic Psychology, 33(6), 1223-1239. https://doi.org/10.1016/j.joep.2012.08.010

Gómez-Ruiz, L., \& Rodríguez-Rivero, E. (2018) The motivational role of consultative participation in a multi-period target setting: An experimental study. Spanish Journal of Finance and Accounting / Revista Española de Financiación y Contabilidad, 47(3), 329-351. https://doi.org/10.1080/02102412.2017.1371978

Groen, B., Wouters, M., \& Wilderom, C. (2017). Employee participation, performance metrics, and job performance: A survey study based on self-determination theory. Management Accounting Research, 36, 51-66. https://doi.org/10.1016/j.mar.2016.10.001

Hair, J. F., Anderson, R. E., Tatham, R. L., \& Black, W. C. (2009). Análise multivariada de dados (6 ed.). Porto Alegre: Bookman.

Hair, J. F., Hult, T. M., Ringle, C. M., \& Sarstedt, M. A. (2014). Primer on partial least squares structural equation modeling (PLS-SEM). Los Angeles: Sage Publications.

Hassel, L. G., \& Cunningham, G. M. (1993). Budget effectiveness in multinational companies: An empirical examination of environmental interaction on cognitive and affective effects of two dimensions of budgetary participation. Scandinavian Journal of Management, 9(4), 299-318. https://doi.org/10.1016/0956-5221(93)90026-O 
Hassel, L. G., \& Cunningham, G. M. (1996). Budget effectiveness in multinational corporations: an empirical test of the use of budget controls moderated by two dimensions of budgetary participation under high and low environmental dynamism. MIR: Management International Review, 36(3), 245-266. https://www.jstor.org/stable/40228360

Hayes, A.F. (2013). Introduction to mediation, moderation, and conditional process analysis: A regression-based approach. New York: The Guilford Press.

Isgiyarta, J., Nugroho, D. A., Ratmono, D., Helmina, M. R. A., \& Pamungkas, I. D. (2019). Budgetary participation on managerial performance: Commitment organization, innovation perception, and job relevant information as mediating variable. Quality - Access to Success, 20(173), 48-53. Retrieved from https://www.srac.ro/calitatea/en/ arhiva/2019/QAS Vol.20 No.173 Dec.2019.pdf

Jacomossi, F., Schlup, D., \& Zonatto, V. C da S. (2018). Efeitos da participação orçamentária na relação entre ambiguidade e conflito de papéis e o desempenho gerencial. Advances in Scientific \& Applied Accounting, 11(3), 391-409. http://doi.org/10.14392/ASAA.2018110302

Ke, W., \& Zhang, P. (2009). Motivations in open source software communities: The mediating role of effort intensity and goal commitment. International Journal of Electronic Commerce, 13(4), 39-66. https://doi.org/10.2753/JEC1086-4415130403

Kren,L. (1992). Budgetaryparticipationand managerial performance: The impact of information and environmental volatility. The Accounting Review, 67(3), 511-552. Retrieved from https://www.jstor.org/stable/247975

Kren, L., \& Liao, W. M. (1988). The role of accounting information in the control of organizations: A review of the evidence. Journal of Accounting Literature, 7(1), 280-309.

Kuvaas, B., Buch,R., Weibel,A., Dysvik,A., \&Nerstad,C.G.L.(2017). Do intrinsic and extrinsic motivation relate differently to employee outcomes? Journal of Economic Psychology, 61, 244-258. https://doi.org/10.1016/j.joep.2017.05.004

Kyj, L., \& Parker, R. J. (2008). Antecedents of budget participation: Leadership style, information asymmetry, and evaluative use of budget. ABACUS - A Journal of Accounting, Finances and Business Studies, 44(4), 423-442. https://doi.org/10.1111/j.1467-6281.2008.00270.x

Lau, C. M., \& Buckland, C. (2001). Budgeting-the role of trust and participation: A research note. Abacus, 37(3), 369388. https://doi.org/10.1111/1467-6281.00092

Lau, C. M., \& Tan, S. L. C. (2006). The effects of procedural fairness and interpersonal trust on job tension in budgeting, Management Accounting Research, 17(2), 171186. https://doi.org/10.1016/j.mar.2005.10.001

Lau, C. M., \& Roopnarain, K. (2014). The effects of nonfinancial and financial measures on employee motivation to participate in target setting. The British Accounting Review, 46(3), 228-247. https://doi.org/10.1016/j.bar.2014.02.006

Lavarda, C. E. F., \& Almeida, D. M. (2013). Budget participation and informational asymmetry: A study in a multinational company. Brazilian Business Review, 10(2), 74-96. https://doi.org/10.15728/bbr.2013.10.2.4
Lavarda, C.E.F., Sant'ana, S.V., Manfroi, L., \& Dagostini, L. (2015). Participação orçamentária e definição das metas orçamentárias em uma cooperativa agroindustrial. ConTexto, 15(30), 20-35. Retrieved from https://seer.ufrgs.br/ConTexto/article/view/43225

Locke, E. A., \& Latham, G. P. (1990). Work motivation and satisfaction: Light at the end of the tunnel. Psychological Science, 1(4), 240-246. https://doi.org/10.1111/j.1467-9280.1990.tb00207.x

Locke, E. A., \& Latham, G. P. (2002). Building a practically useful theory of goal setting and task motivation. American Psychologist, 57(9), 705-717. https://doi.org/10.1037//0003-066x.57.9.705

Locke, E. A., Motowidlo, S., \& Bobko, P. (1986). Using selfefficacy theory to resolve the conflict between goalsetting theory and expectancy theory in organizational behavior and industrial/organizational psychology. Journal of Social and Clinical Psychology, 4(3), 328-338. https://doi.org/10.1521/jscp.1986.4.3.328

Locke, E. A., \& Latham, G. P. (2004). What should we do about motivation theory? Six recommendations for the twentyfirst century. The Academy of Management Review, 29(3), 388-403. https://doi.org/10.2307/20159050

Lunardi, M. A., Zonatto, V. C. D. S., \& Nascimento, J. C. (2020). Mediating cognitive effects of information sharing on the relationshipbetweenbudgetaryparticipationandmanagerial performance. Revista Contabilidade \& Finanças, 31(82), 14-32. https://doi.org/10.1590/1808-057x201908610

Macinati, M. S., \& Rizzo, M. G. (2014). Budget goal commitment, clinical managers' use of budget information and performance. Health Policy, 117(2), 228-238. https://doi.org/10.1016/j.healthpol.2014.05.003

Maiga, A. S. (2005). Antecedents and consequences of budget participation. Advances in Management Accounting, 14, 211 231. https://doi.org/10.1016/S1474-7871(05)14010-6

Mathieu, J. E., \& Zajac, D. M. (1990). A review and meta-analysis of the antecedents, correlates, and consequences of organizational commitment. Psychological Bulletin, 108(2), 171-194. https://doi.org/10.1037/0033-2909.108.2.171

Meyer, J. P., Becker, T. E., \& Vandenberghe, C. (2004). Employee commitment and motivation: A conceptual analysis and integrative model. Journal of Applied Psychology, 89(6), 991-1007. https://doi.org/10.1037/0021-9010.89.6.991

Meyer, J. P., \& Herscovitch, L. (2001). Commitment in the workplace: Toward a general model. Human Resource Management Review, 11(3), 299-326. https://doi.org/10.1016/S1053-4822(00)00053-X

Mia, L. (1988). Managerial attitude motivation and the effectiveness of budget participation. Accounting, Organizations and Society,13(5), 465-475. https://doi.org/10.1016/0361-3682(88)90017-7

Mia, L. (1989). The impact of participation in budgeting and job difficulty on managerial performance and work motivation: A research note. Accounting, Organizations and Society, 14(4), 347-357. https://doi.org/10.1016/0361-3682(89)90005-6 
Milani, K. (1975). The relationship of participation in budgetsetting to industrial supervisor performance and attitudes: A field study. The Accounting Review, 50(2), 274-284. Retrieved from https://www.jstor.org/stable/244709

Mucci, D. M., Frezatti, F., \& Dieng, M. (2016). As múltiplas funçóes do orçamento empresarial. Revista de Administração Contemporânea, 20(3), 283-304. https://doi.org/10.1590/1982-7849rac2016140121

Murray, D. (1990). The performance effects of participative budgeting: An integration of intervening and moderating variables. Behavioral Research in Accounting, 2(2), 104-123. Retrieved from https://www.researchgate.net/publication/283918495

Nouri, H., \& Kyj, L. (2008). The effect of performance feedback on prior budgetary participative research using survey methodology: An empirical study. Critical Perspectives on Accounting, 19(8), 1431-1453. https://doi.org/10.1016/j.cpa.2007.11.003

Nouri, H., \& Parker, R. J. (1998). The relationship between budget participation and job performance: The roles of budget adequacy and organizational commitment. Accounting, Organizations and Society, 23(5-6), 467-483. https://doi.org/10.1016/S0361-3682(97)00036-6

Parker, R. J., \& Kyj, L. (2006). Vertical information sharing in the budgeting process. Accounting, Organizations and Society, 31(1), 27-45. https://doi.org/10.1016/j.aos.2004.07.005

Pinder, W. C. C. (2011). Work motivation in organizational behavior (2. ed.). New York: Psychology Press, Taylor \& Francis.

Podsakoff, P. M., MacKenzie, S. B., Lee, J.-Y., \& Podsakoff, N. P. (2003). Common method biases in behavioral research: A critical review of the literature and recommended remedies. Journal of Applied Psychology, 88(5), 879-903. https://doi.org/10.1037/0021-9010.88.5.879

Rachman, A. A (2014). The effect of organization commitment and procedural fairness on participative budgeting and its implication to performance moderating by management accounting information. Review of Integrative Business and Economics Research, 3(1), 201-218. Retrieved from: https://www.proquest.com/docview/1513215318

Reid, P. (2002). A critical evaluation of the effect of participation in budget target setting on motivation. Managerial Auditing Journal, 17(3), 122-129. https://doi.org/10.1108/02686900210419903

Revista Exame (2017, August). Melhores e maiores - As 1.000 maiores empresas do Brasil. Retrieved from https://exame. abril.com.br/revista-exame/1000-maiores-empresas/

Ryan, R. M., \& Deci, E. L. (2000). Self-determination theory and the facilitation of intrinsic motivation, social development and well-being. American Psychologist, 55(1), 68-78. http://doi.org/10.1037//0003-066x.55.1.68

Santos, A. C. D., Lavarda, C. E. F., \& Marcello, I. E. (2014). The relationship between cost management knowledge and budgetary participation with managers' performance. Revista Brasileira de Gestão de Negócios, 16(50), 124-142. http://doi.org/10.7819/rbgn.v16i50.1236
Sholihin, M., Pike, R. Mangena, M., \& Li, J. (2011). Goalsetting participation and goal commitment: Examining the mediating roles of procedural fairness and interpersonal trust in a UK financial services organization. The British Accounting Review, 43(2), 135-146. https://doi.org/10.1016/j.bar.2011.02.003

Shields, J. F., \& Shields, M.D. (1998). Antecedents of participative budgeting. Accounting, Organizations and Society, 23(1), 49-76. https://doi.org/10.1016/S0361-3682(97)00014-7

Stearns, J. J. P. (2016). The moderating effects of personality on the relationship between budget participation and motivation to reach the budget goal. International Journal of Business, Accounting, and Finance, 10(1), 144-165. Retrieved from https://www.iabpad.com/the-moderating-effectsof-personality-on-the-relationship-between-budgetparticipation-and-motivation-to-reach-the-budget-goal/

Subramaniam, N., \& Mia, L. (2001). The relation between decentralized structure, budgetary participation and organizational commitment: The moderating role of managers' value orientation towards innovation. Accounting, Auditing \& Accountability Journal, 14(1), 1230. http://doi.org/10.1108/09513570110381051

Vallerand, R. J. (1997). Toward a hierarchical model of intrinsic and extrinsic motivation. Advances in Experimental Social Psychology, 29, 271-360. https://doi.org/10.1016/S0065-2601(08)60019-2

Van der Kolk, B., Van Veen-Dirks, P. M. G, \& Bogt, H. J. T. (2019). The impact of management control on employee motivation and performance in the public sector. European Accounting Review, 28(5), 901-928. https://doi.org/10.1080/09638180.2018.1553728

Wafiroh, N. L., Abdani, F., \& Nurdin, F. (2020). Budget participation and budgetary slack: The mediating effect of autonomous budget motivation. Jurnal Akuntansi,10(3), 287-300. https://doi.org/10.33369/j.akuntansi.10.3.287-300

Welsh, D. T., Baer, M. D., Sessions, H., \& Garud, N. (2020). Motivated to disengage: The ethical consequences of goal commitment and moral disengagement in goal setting. Journal of Organizational Behavior, 41(7), 663-677. https://doi.org/10.1002/job.2467

Wentzel, K. (2002). The influence of fairness perceptions and goal commitment on managers' performance in a budget setting. Behavioral Research in Accounting, 14(1), 247-271. https://doi.org/10.2308/BRIA.2002.14.1.247

Wong-On-Wing, B., Guo, L., \& Lui, G. (2010). Intrinsic and extrinsic motivation and participation in budgeting: Antecedents and consequences. Behavioral Research in Accounting, 22(2), 133-153. https://doi.org/10.2308/bria.2010.22.2.133

Zonatto, V. C. da S., Nascimento, J. C., Lunardi, M. A., \& Degenhart, L. (2020). Effects of budgetary participation on managerial attitudes, satisfaction, and managerial performance. Revista de Administração Contemporânea, 24(6), 532-549. https://doi.org/10.1590/1982-7849rac2020200047

Zonatto, V. C. S., Weber, A., \& Nascimento, J. C. (2019). Efeitos da participação orçamentária na assimetria informacional, estresse ocupacional e desempenho gerencial. Revista de Administração Contemporânea, 23(1), 67-91. https://doi.org/10.1590/1982-7849rac2019170327 


\section{Authorship}

\section{Daniele Cristina Bernd*}

Universidade Federal de Santa Catarina, Programa de Pósgraduação em Contabilidade

Rua Roberto Sampaio Gonzaga, no 274, Trindade, 88040-380, Florianópolis, SC, Brazil.

E-mail address: dcbernd@hotmail.com

(D) https://orcid.org/0000-0002-9195-9510

\section{Ilse Maria Beuren}

Universidade Federal de Santa Catarina, Programa de Pósgraduação em Contabilidade

Rua Roberto Sampaio Gonzaga, no 274, Trindade, 88040-380, Florianópolis, SC, Brazil.

E-mail address: ilse.beuren@gmail.com

(D) https://orcid.org/0000-0003-4007-6408

\section{Celliane Ferraz Pazetto}

Universidade Federal de Santa Catarina, Programa de Pósgraduação em Contabilidade

Rua Roberto Sampaio Gonzaga, no 274, Trindade, 88040-380, Florianópolis, SC, Brazil.

E-mail address: cellianeferraz@gmail.com

(D) https://orcid.org/0000-0002-7413-1981

\section{Carlos Eduardo Facin Lavarda}

Universidade Federal de Santa Catarina, Programa de Pósgraduação em Contabilidade

Rua Roberto Sampaio Gonzaga, no 274, Trindade, 88040-380, Florianópolis, SC, Brazil.

E-mail address: eduardo.lavarda@ufsc.br

(D) https://orcid.org/0000-0003-1498-7881

${ }^{*}$ Corresponding Author

\section{Funding}

The authors reported that there is no financial support for the research in this article.

\section{Conflict of Interests}

The authors have stated that there is no conflict of interest.

\section{Plagiarism Check}

The RAC maintains the practice of submitting all documents approved for publication to the plagiarism check, using specific tools, e.g.: iThenticate.

\section{Copyrights}

RAC owns the copyright to this content.

\section{Authors' Contributions}

$\mathbf{1}^{\text {st }}$ author: conceptualization (lead); data curation (equal); formal analysis (equal); investigation (equal); methodology (lead); project administration (equal); validation (lead); visualization (equal); writing-original draft (equal); writingreview \& editing (lead).

$2^{\text {nd }}$ author: conceptualization (equal); data curation (supporting); formal analysis (equal); investigation (equal); methodology (equal); project administration (lead); software (supporting); supervision (lead); validation (equal); visualization (equal); writing-original draft (supporting); writing-review \& editing (lead).

$3^{\text {rd }}$ author: conceptualization (equal); data curation (lead); investigation (equal); methodology (equal); software (equal); validation (equal); visualization (equal); writing-original draft (equal); writing-review \& editing (supporting).

$4^{\text {th }}$ author: conceptualization (equal); formal analysis (equal); investigation (equal); methodology (supporting); project administration (supporting); supervision (supporting); visualization (supporting); writing-original draft (supporting); writing-review \& editing (supporting).

\section{Peer Review Method}

This content was evaluated using the double-blind peer review process. The disclosure of the reviewers' information on the first page, as well as the Peer Review Report, is made only after concluding the evaluation process, and with the voluntary consent of the respective reviewers and authors.

\section{Data Availability}

The authors chose not to share their database and affirm that they do so in view of that in the research cover letter, the subjects of the research were assured of the broad secrecy and privacy of their answers and other information that would allow them not to be associated with their positions and companies.

RAC encourages data sharing but, in compliance with ethical principles, it does not demand the disclosure of any means of identifying research subjects, preserving the privacy of research subjects. The practice of open data is to enable the reproducibility of results, and to ensure the unrestricted transparency of the results of the published research, without requiring the identity of research subjects. 


\section{APPENDIX A.}

Table A1. Research instrument.

\begin{tabular}{|c|c|c|c|c|c|c|c|c|}
\hline Construct & Items & Description & Load & Average & $\mathrm{DP}$ & AVE & $\begin{array}{l}\text { Cronbach's } \\
\text { alpha }\end{array}$ & $\begin{array}{l}\text { Conf. } \\
\text { composed }\end{array}$ \\
\hline \multirow{6}{*}{ 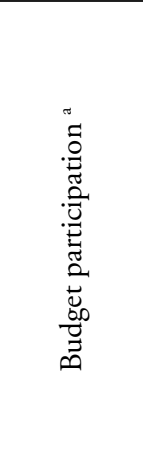 } & $\mathrm{CO} 1$ & $\begin{array}{l}\text { Level of influence you exert on the final budget } \\
\text { of your area. }\end{array}$ & 0.792 & \multirow{6}{*}{5.05} & \multirow{6}{*}{1.58} & \multirow{6}{*}{0.649} & \multirow{6}{*}{0.891} & \multirow{6}{*}{0.917} \\
\hline & $\mathrm{CO} 2$ & Portion of your involvement in budgeting. & 0.827 & & & & & \\
\hline & $\mathrm{CO} 3$ & $\begin{array}{l}\text { The importance of your contribution to the } \\
\text { budget. }\end{array}$ & 0.731 & & & & & \\
\hline & $\mathrm{IO} 1$ & $\begin{array}{l}\text { Frequency of budget-related discussions initiated } \\
\text { by supervisors. }\end{array}$ & 0.791 & & & & & \\
\hline & $\mathrm{IO} 2$ & $\begin{array}{l}\text { Frequency of budget-related discussions initiated } \\
\text { by you. }\end{array}$ & 0.853 & & & & & \\
\hline & $\mathrm{IO} 3$ & $\begin{array}{l}\text { Type of justification given to you when the budget } \\
\text { is reviewed. }\end{array}$ & 0.832 & & & & & \\
\hline \multirow{6}{*}{ 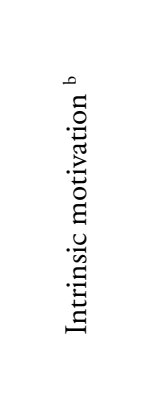 } & MINTR1 & $\begin{array}{l}\text { The tasks I do represent a driving force in my } \\
\text { work. }\end{array}$ & outcast & \multirow{6}{*}{5.47} & \multirow{6}{*}{1.31} & \multirow{6}{*}{0.718} & \multirow{6}{*}{0.883} & \multirow{6}{*}{0.91} \\
\hline & MINTR2 & The tasks I do at work are enjoyable. & 0.826 & & & & & \\
\hline & MINTR3 & My work is relevant. & outcast & & & & & \\
\hline & MINTR4 & My work is very exciting. & 0.904 & & & & & \\
\hline & MINTR5 & $\begin{array}{l}\text { My work is so interesting that it's a motivation in } \\
\text { itself. }\end{array}$ & 0.908 & & & & & \\
\hline & MINTR6 & $\begin{array}{l}\text { Sometimes I'm so excited about my work that I } \\
\text { pretty much forget everything around me. }\end{array}$ & 0.740 & & & & & \\
\hline \multirow{4}{*}{ 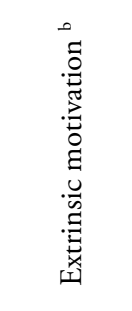 } & MEXTR1 & If I need to work harder, I have to earn more. & 0.810 & \multirow{4}{*}{2.95} & \multirow{4}{*}{1.72} & \multirow{4}{*}{0.638} & \multirow{4}{*}{0.738} & \multirow{4}{*}{0.839} \\
\hline & MEXTR2 & $\begin{array}{l}\text { It is important to have an external incentive for } \\
\text { me to motivate myself in doing a good job. }\end{array}$ & outcast & & & & & \\
\hline & MEXTR3 & $\begin{array}{l}\text { External incentives like bonuses and provisions are } \\
\text { essential to determine how well I perform my job. }\end{array}$ & 0.688 & & & & & \\
\hline & MEXTR4 & $\begin{array}{l}\text { If I'd been offered a better salary, I would have } \\
\text { done a better job. }\end{array}$ & 0.885 & & & & & \\
\hline \multirow{4}{*}{ 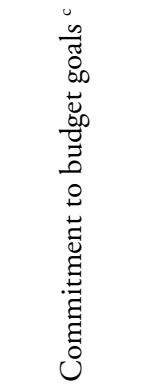 } & $\mathrm{CMO} 1$ & I care about achieving the budget goals of my area. & 0.762 & \multirow{4}{*}{5.96} & \multirow{4}{*}{1.31} & \multirow{4}{*}{0.637} & \multirow{4}{*}{0.715} & \multirow{4}{*}{0.84} \\
\hline & $\mathrm{CMO} 2$ & It's hard for me to abandon my area's budget goals. & 0.795 & & & & & \\
\hline & $\mathrm{CMO} 3$ & $\begin{array}{l}\text { I create expectations of achieving the budget goals } \\
\text { of my area. }\end{array}$ & 0.835 & & & & & \\
\hline & $\mathrm{CMO} 4$ & $\begin{array}{l}\text { Given that it is not always possible to say how } \\
\text { difficult it is to meet the budget, unless you have } \\
\text { worked on it for some time, it is difficult to take } \\
\text { budget targets seriously (R). }\end{array}$ & outcast & & & & & \\
\hline
\end{tabular}

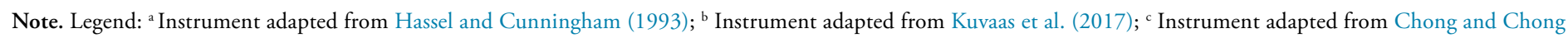
(2002); (R) Reverse question. All constructs used a seven-point Likert scale (1 to 7), which ranged from: very low/very high ${ }^{\mathrm{a}}$; and I totally disagree/totally agree ${ }^{\mathrm{b}, \mathrm{c}}$. 